\title{
Evaluación de la eficacia de una reparación para hormigón contaminado con cloruros
}

\section{Evaluation of the efficiency of a repaired chloride-contaminated concrete}

\begin{abstract}
RESUMEN
En el presente trabajo se describen los ensayos que se están efectuando en un viaducto de las cercanias de Madrid y que ha sufrido importantes daños por corrosión de armaduras. Estos Ensayos consisten en la medida de los potenciales de corrosión y en un próximo futuro, de la velocidad de corrosión (método de la Resistencia de Polarización Aparente).

También se presenta la metodología de los ensayos de laboratorio efectuados para caracterizar la capacidad protectora hacia las armaduras del sistema de reparacion utilizado en el viaducto. Los resultado de estos ensayos han mostrado que los materiales de reparación no resultan idóneos para la función repasivante y protectora que deberán desempeñar. Se destaca, finalmente, la necesidad de desarrollar una normativa de ensayos adecuada que permita caracterizar a estos materiales de reparación cuando van a ser usados en obras dañadas por corrosión de armaduras.

\section{ANDRADE, B. BACLE, C. ALONSO}

IETCC/CSIC

Serrano Galvache, s/n - MADRID - España

J. M. CONDE-SALAZAR

Laboratorio Geocisa

\author{
SUMMARY \\ This report describes several tests that are being carried \\ out on a viaduct near Madrid City, whose reinforcements \\ have been seriously damaged by corrosion. These tests \\ consist in measuring corrosion potentials and in a time \\ soon to come, they will include the measurement of \\ corrosion rates by means of the apparent Polarization \\ Resistance.
}

A methodology of laboratory tests to evaluate the protective capacity of the repairing system used towards the reinforcements is also included. Tests results have reported that the repairing materials employed do not fit the repassivating and protective function they should satisfy. Finally, it is also recailed to attention the real need in developing suitable test specifications able to provide a characterization of these repairing materials when they are going to be employed in structures damaged by corrosion in reinforcements.

\section{INTRODUCCION}

Los casos de deterioros de puentes debido al uso de sales de deshielo no es, por fortuna, frecuente en nuestro país debido a su benigno clima. Sin embargo, son cada vez más numerosos los deterioros a consecuencia de! ataque de los ambientes marinos sobre estructuras de hormigón.

En ambos casos, los cloruros que penetran a través de los poros del hormigón provocan la corrosión de las armaduras, lo que lleva en un periodo de tiempo, más o menos largo, a un nivel de daños (fisuras, manchas de óxido, etc.) elevado y se plantea la necesidad de proceder a reparar o reforzar la estructura.

\section{INTRODUCTION}

Fortunately, damages in bridges caused by the employment of melting-ice salt are rather anusual in our mild climate country. However, damages in concrete structures produced by the attack of marine media are becoming more and more numerous.

In both cases, chlorides penetrate through the concrete's pores producing corrosion of reinforcements, process which in shorter or longer terms causes serious damages (fissures, oxide spots,...etc) and necessary repairs on the structure reinforcements. 
A pesar de que ya hace muchos años que se reparan estructuras de hormigón, sorprende la poca literatura científica en la que se puede encontrar referencias sobre la durabilidad de las propias reparaciones. Sobre materiales para reparación de obras dañadas por corrosión de armaduras existe una gran cantidad de información comercial y se han redactado incluso manuales, normas y recomendaciones de uso (1) (2) (3) que permíten caracterizar su naturaleza y las propiedades mecánicas y de adherencia de los materiales soporte, pero poco se encuentra que permita conocer sus propiedades con respecto a la función básica que van a desempeñar, es decir, sobre su capacidad para repasivar las armaduras y su capacidad impermeabilizante.

Así, cuando es necesario tomar decisiones sobre una obra concreta, no se encuentran fácilmente los criterios básicos con los que juzgar la mayor o menor bondad y durabilidad a largo plazo de entre la oferta de materiales de reparación, que se encuentra disponible comercialmente.

En el presente trabajo se describe la serie de ensayos que se han abordado para dictaminar sobre la capacidad protectora de un sistema de reparación que se ha aplicado en un viaducto cuyas armaduras se han dañado por el uso de sales de deshielo y que, debido al vacío científico existente, la Empresa propietaria ha querido conocer.

\section{Descripción de la obra}

El viaducto objeto de la reparación está situado en las cercanías de Madrid, en su zona Norte, figura 1. Consta de diez vanos isostáticos de vigas postensadas con $36 \mathrm{~m}$ de luz.
In spite of the fact that repairing concrete structures has been very usual for years, it is amazing how few scientific references can be found concerning the durability of these repairs. On the contrary, there is a great deal of commercial information concerning materials employed in repairing structures damaged by corrosion of reinforcements. This information is provided by a great number of commercial guides, manuals and recommedation books (1), (2), (3) by which materials can be characterized by their nature, mechanical and adherence properties. However, little information can be found concerning their properties in relation to the task they are going to perform, that is to say, in relation to their repassivating capacity on reinforcements and impermeabilizing characteristics.

Thus, when a decision on a given repairing project must be taken, it is not easily found basical criteria by which it could be more or less accurately determined, the durability in the long term of the repairing materials found in the market.

This report describes several tests performed to study the protective capacity of the repaired system applied to a viaduct whose reinforcements have been damaged because of the employement of melting-ice salts.

\section{Building description}

The viaduct subject of repairing is located at the northern outskirt of Madrid City, Fig. 1. It has ten isostatic spans of poststressed beams $36 \mathrm{~m}$ apart from each other.

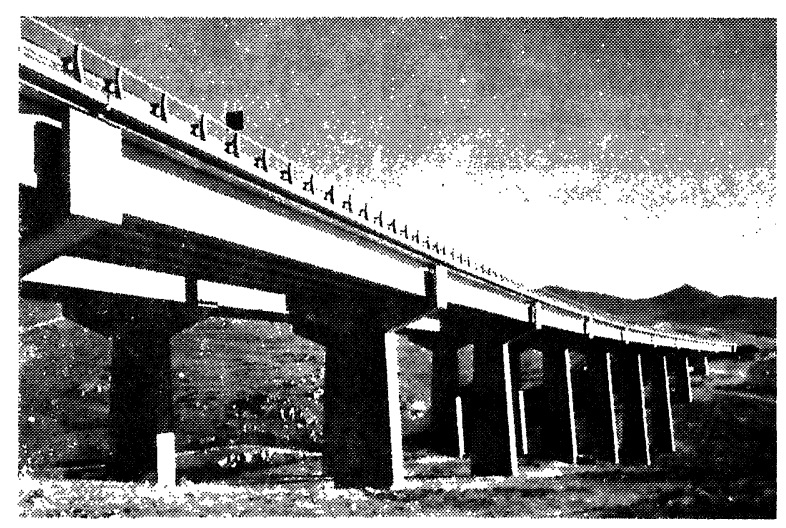

Fig. 1.-Vista general del viaducto.

Fig. 1.-Viaduct's general view. 
El número de tendones por viga es de 16, con doce alambres de $7 \mathrm{~mm}$ de diámetro por tendón. El recubrimiento teórico mínimo de los tendones es de $7 \mathrm{~mm}$. El árido utilizado es granítico y la resistencia media del hormigón es de $350 \mathrm{Kg} / \mathrm{cm}^{2}$.

Los primeros daños aparecieron cuando la estructura tenía 10 años de vida, y la primera reparación importante ha sido abordada cuando tiene 15 años. En este momento existían ya bastantes zonas deterioradas, especialmente las aceras, las alas laterales de las vigas exteriores y las cabezas de los pilares. Los deterioros se intensificaban en estás áreas debido a un incorrecto drenaje de las aguas, que hace que las mismas circulen por la superficie del hormigón, en vez de ser evacuadas por canalizaciones especiales.

Antes de acometer los trabajos de esta reparación, en una de las vigas más afectadas, se realizaron pruebas con distintos productos de reparación de casas comerciales acreditadas, utilizándose en todas las pruebas la misma metodología de reparación, con el fin de conocer el comportamiento de estos in situ al no venir avalados con ensayos específicos.

Al cabo de un año se observaron nuevamente manchas de óxido y fisuras en prácticamente todas las zonas en prueba. Para abordar la reparación definitiva se eligió el material que mejor se comportó en estas pruebas. Se reconstituyó, finalmente, la zona con el material de reparación elegido. La reparación se realizó sólo en aquellas zonas que se detectaron exteriormente como deterioradas. Se procedió al saneamiento previo en profundidad de las zonas a reparar; con eliminación del hormigón afectado hasta $3 \mathrm{~cm}$ por detrás de la armadura, en todo caso hasta que la alcalinidad del hormigón tenía los valores normales (elevados) de uno sano. Esta circunstancia se comprobó con un producto a base de fenolftaleina. Finalmente se pintaron las alas laterales de las vigas exteriores con una pintura anticarbonatación (tres manos).

Con posterioridad a la elección del sistema de reparación se solicitó asesoramiento al IETcc, para el seguimiento y control de la misma. Los técnicos del IETcc encargados del tema plantearon la posibilidad de un seguimiento in situ de la estructura, con el fin de detectar prematuramente una nueva despasivación y corrosión y también la necesidad de una evaluación en el laboratorio de la capacidad pasivante e impermeabilizante del sistema de reparación utilizado.
The number of tendons per beam is 16 , with 12 wires $7 \mathrm{~mm}$ width per tendon. Tendon minimum theorical cover is $7 \mathrm{~cm}$. The aggregate employed was granitical and the average resistance of the concrete is $350 \mathrm{Kg} / \mathrm{cm}^{2}$.

First damages appeared when the structure was 10 years old and the first important repair was undertaken when it was 15 . In this moment, there were many damages zones, especially at the road sides, the lateral wings of the external beams and at the upper head of the pillars. Damages were more numerous in these zones because of the inadequate draining of water, so that water circulated on the concrete's surface instead of being removed through special canalizations.

Before repairing works were carried out several repairing products of different wellaccredited commercial suppliers were tested on one of the most damaged beams. All these tests employed the same repairing methodology in order to know in-situ the behaviours of the different materials as there was no verification with any specific test.

A year later, almost every repaired zone showed new fissures and oxide spots. In order to carry out the final repairing, it was selected that material that proved to have the best behaviour on tests. Finally, it was rebuilt the zone with the repairing material selected. Repairing was only performed on those zones which had external marks of damage. The zones to be repaired were previously cleaned in depth and damaged concrete removed off 3 $\mathrm{cm}$ behind the reinforcements or at least, as deep as the concrete alkalinity have normal (high) values of a sane concrete. This normal alkalinity was verified by means of a phenolothalein product. Finally, the lateral wings of the external beams were (three times) painted with an anticarbonation paint.

Before it was selected the repairing system, it was asked some advise to IETCC concerning the checking and control system of the repaired structure. IETCC technicians pointed out the possibility of checking the structure in-situ so that a new depassivating and corrosion could be prematurely detected. It was also put forward the need in evaluating in laboratory the passivating capacity and impermeabilizing characteristics of the repairing system employed. 


\section{ENSAYOS IN SITU}

Aprovechando la ejecución de los trabajos de reparación se procedió, en dos puntos del viaducto, a dejar al exterior contactos eléctricos con las armaduras, tanto activas (vainas con cables de pretensado) como pasivas, así como testigos de pequeño tamaño.

Así, pues, se embebieron dos trozos de armaduras de $8 \mathrm{~mm}$ de diámetro y de 6 y $20 \mathrm{~cm}$ de longitud paralelos a las armaduras pasivas, pero sin contacto eléctrico con ellas, de tal forma que el recubrimiento de hormigón fuera similar en los testigos y en las armaduras pasivas. También se dejaron contactos eléctricos con una de las vainas y con la propia armadura pasiva. Finalmente se embebieron unos electrodos de $\mathrm{Ag} / \mathrm{ClAg}$ fabricados en el laboratorio.

Cada seis meses se procede a medir los potenciales de corrosión y se están haciendo los ensayos y diseño de aparatos adecuados para proceder a medir también la velocidad de corrosión. A este respecto, hay que señalar que, si bien la medida de los potenciales de corrosión es ya una práctica habitual (4), la medida de la velocidad de corrosión en grandes estructuras es todavía un tema no resuelto a nivel mundial y en el que los investigadores del IETcC, que trabajan en colaboración con otros del CENIM, están realizando aportaciones valiosas (5), aunque todavía quedan muchas cuestiones por resolver en los aspectos prácticos.

El $E_{\text {corr }}$ necesita para ser medido un simple milivoltímetro portátil y un electrodo de referencia, en cambio la medida de la $I_{\text {corr }}$ por el método de la Resistencia de Polarización, Rp (que es el desarrollado por el IETcc y CENIM) necesita en la parte instrumental al menos un potenciostato de diseño especial. En los aspectos teóricos, es necesario contar con fórmulas matemáticas adecuadas con objeto de interpretar la señal eléctrica aplicada a elementos metálicos de longitud quasi-infinita.

\section{Resultados}

Hasta el momento se han realizado medidas de $E_{\text {corr }}$, y notables avances en el campo de la Instrumentación necesaria para medir $\mathrm{I}_{\text {corr }}$. Los valores de $E_{\text {corr }}$ permanecen constantes $y$ alrededor de $+200 \mathrm{~m} \mathrm{~V}_{\mathrm{ECS}}$ en la zona Norte del viaducto, y alrededor de $-100 \mathrm{mV}$ en la zona Sur.

De los resultados de $E_{\text {corr }}$ se deduce que el acero permanece pasivo desde el momento

\section{IN SITU TESTS}

As repairing works were carried out, it was left in two points of the viaduct external electric contacts with the reinforcements, both loaded (sheathes with prestressed cables) and unloaded ones, as well as small sized corrugated bars.

Thus, two pieces of rebars $8 \mathrm{~mm}$ width and 6 and $20 \mathrm{~cm}$ long were embedded parallely to the unloaded reinforcements but without any electric contact between them, in such a way that the concrete cover was similar to the small bars embedded in unloaded reinforcements of the structure. Some electric contacts were also moded with one of the sheathes and with the loaded reinforcement. Finally, electrodes of $\mathrm{Ag} / \mathrm{ClAg}$ made in laboratory were embedded.

Each six months, corrosion potentials were measured and parallelly, a suitable equipment was being designed in order to measure corrosion rates, indeed. In relation to this point, it should be remarked that although the measurement of corrosion potentials is a regular practice (4), the measurement of corrosion rates in large structures is still a worldwide unsolved question. IETCC researchers working together with CEMIN researchers are valuably contributing in solving this question, (5), though there are still many practical points to be solved.

Measuring $E_{\text {corr }}$ requires a simple portable potentiontat and a reference electrode, while, measuring $I_{\text {corr }}$ by means of the Polarization Resistance $R p$ (method employed and developed by the IETCC and the CENIM) requieres at least a portable potentiostat and a counterelectrode with a special design. Theorically, it is necessary some suitable mathematical formula in order to interpret the electric sign applied to the metallic elements of almost infinite length.

\section{Results}

At this moment, the measurement of $E_{\text {corr }}$ and remarkable progress in developing suitable equipment for measuring $I_{\text {corr }}$ have been carried out. $E_{\text {corr }}$ values stay constant around $+200 \mathrm{mV} \mathrm{V}_{\text {SCE }}$ at the northern zone of the viaduct and $-100 \mathrm{mV}$ at the southern site.

From $E_{\text {corr }}$ obtained, it is deduced that the steel stays passive the time after it was repaired. 
que se aplicó la reparación, si bien al ser los resultados de la zona Sur del viaducto unos $300 \mathrm{mV}$ más negativos que los de la zona Norte, se interpretó como que la armadura en la zona Sur estaba menos protegida. Esta sospecha fue confirmada con una observación visual detallada de esta área, en la que se pudo detectar una microfisuración generalizada, atribuible en principio por su apariencia a retracción térmica del mortero de reparación empleado. Esta fisuración ha obligado a una nueva intervención para sellar las fisuras y proceder a un nuevo pintado de acabado.

Destacan finalmente que los elementos de $\mathrm{Ag} / \mathrm{ClAg}$ embebidos presentan un potencial estable pero muy alejado del que teóricamente deberian tener, por lo que se mide siempre además con un electrodo de calomelanos saturado que se sitúa sobre el hormigón en cada medida. Uno de los objetivos es conocer la estabilidad de ios electrodos de $\mathrm{Ag} / \mathrm{CIAg}$ cuando se dejan embebidos en el hormigóri.

\section{ENSAYOS DE LABORATORIO}

Estos tenían por objeto el conocer la capacidad protectora hacia las armaduras del sistema de reparación empleado, con el fin de poder prever en lo posible su durabilidad.

El sistema de reparación consiste en:

A. Una pintura para las armaduras (no es epoxil).

B. Un mortero especial denominado "sin retracción".

C. Una pintada de acabado denominada "anticarbonatación".

Los ensayos que se efectuaron fueron los siguientes:

Tipo 1. Ensayos sobre la capacidad resistente de la pintura $\mathrm{C}$ al paso del $\mathrm{CO}_{2}$.

Tipo 2. Ensayos sobre la capacidad resistente del mortero B y la pintura A a la penetración de cloruros.

Tipo 3. Eficacia de la pintura A como protectora frente al ataque de los cloruros.

Sobre la metodología de estos ensayos existen referencias en el caso de los cloruros, ya que algunos investigadores han
Results of the southern zone were $300 \mathrm{mV}$ more negative than those obtained ai the northern sites, what was interpreted as the reinforcements of the southern sites were less protected. This assumption was verified by a detailed visual examination on this area in which it was detected general microfissuring firstiy due according to its appearance, to a thermal retraction of the repairing mortar employed. This fissuring process has obliged to restart the repairing in order to seal the fissures and to provide the zone a new finish paint

Finally, it is pointed out that the Ag/CIAg electrodes embedded have a stable potential but far different to the one they theorically should have. For this reason, it is always measured with a saturated calomel electrode which is put on the concret surface for each measurement. One of the aims is to to know the stability of $\mathrm{Ag} / \mathrm{ClAg}$ electrodes when are embedded in concrete.

\section{LABORATOTY TESTS}

Laboratory tests were moded to determine the protective capacity of the repairing system employed towards reinforcements in order to Foresee as much as possible its durability.

The repairing system is made up by the following elements:

\section{A. Paint for reinforcements.}

B. Special mortar.

C. Finish anticarbonation paint

The following tests were performed:

Type 1. Tests with paint $C$ to determine the resistance to $\mathrm{CO}_{2}$ penetration.

Type 2. Tests with mortar $B$ and paint $A$ to study the resistance to chloride penetration.

Type 3. Efficiency of paint towards chloride attacks.

In relation to the methodology for chloride tests some researchers have developed several test procedures. In these cases, for 
desarrollado diversas sistemáticas de ensayo. En el caso presente, para cumplimentar el tipo 2 se han realizado ensayos de ciclos de inmersión-secado en solución concentrada de $\mathrm{NaCl}$ y para el tipo 3, se añadió un $3 \%$ (en relación al peso de cemento) de $\mathrm{NaCl}$ y de $\mathrm{CaCl}_{2}$, en el agua de amasado.

En el caso de los ensayos que permitan determinar la capacidad resistente al paso del $\mathrm{CO}_{2}$, de una pintura para hormigón, no existen más referencias que los ensayos propuestos por la Universidad de Dormund (Alemania Federal) que son los que expresan la resistencia al paso del $\mathrm{CO}_{2}$ con el "equivalente en volumen de aire", pero que no ensayan la pintura utilizando mortero u hormigón como soporte, y por lo tanto se alejan de la realidad. Aquí se ha utilizado una metodología desarrollada en el IETcc y basada en una carbonatación acelerada del conjunto mortero/pintura.

\section{Materiales y métodos}

Se fabricaron probetas para los tres tipos de ensayo antes enumerados.

Para los ensayos tipo 1 de resistencia a la carbonatación, se fabricaron probetas de mortero $\mathrm{c} / \mathrm{a}=1 / 3 \mathrm{y} \mathrm{a} / \mathrm{c}=0,5$, con cemento $\mathrm{P}-450-\mathrm{ARI}$ y de dimensiones $2 \times 5,5 \times 8 \mathrm{~cm}$. En estas probetas se embebieron unos redondos que actúan como "sensores" de la llegada del $\mathrm{CO}_{2}$, ya que se despasivan. Una vez amasadas las probetas se curaron durante 28 días en cámara húmeda. Una serie se pintó con la pintura $\mathrm{C}$ anticarbonatación y otra se dejó sin pintar como testigo.

El aspecto de las probetas se aprecia en la figura 2. tests type 2 immersion-drying cycles in concentrated solution of $\mathrm{NaCl}$ has been carried out. For type 3, it was added $3 \% \mathrm{NaCl}_{2}$ and $3 \% \mathrm{CaCl}_{2}$ as funtion of cement weight to the mixing water.

For those test, in determining the resistance capacity to $\mathrm{CO}_{2}$ of a paint concrete, there is no references except those tests proposed by the University of Dormund (West Germany) in which the resistance capacity to $\mathrm{CO}_{2}$ is given in terms of "equivalent to air volume" but paint are not tested employing mortar or concrete as supporter and therefore, these tests do not fit reality. In this work, a methodology developed by the IETCC has been employed based on an accelerated carbonation of the system mortar/paint.

\section{Materials and methods}

Specimens for each type of test mentioned were made as follows: For resistance to carbonation study (test of type 1), specimens of mortar $\mathrm{c} / \mathrm{s}=1 / 3$ and $\mathrm{w} / \mathrm{c}=0.5$ with ordinarty portland cement, $2 \times 5.5 \times 8 \mathrm{~cm}$ size. Rebars were embedded in these specimens. These rebars are like sensors to $\mathrm{CO}_{2}$ penetration as they are despassivated when carbonation reaches them. After mixing, specimens were submitted to a curing period of 28 days in humid atmosphere. After that a number of them were painted with anticarbonation paint $C$ and others were not painted at all and used as blank.

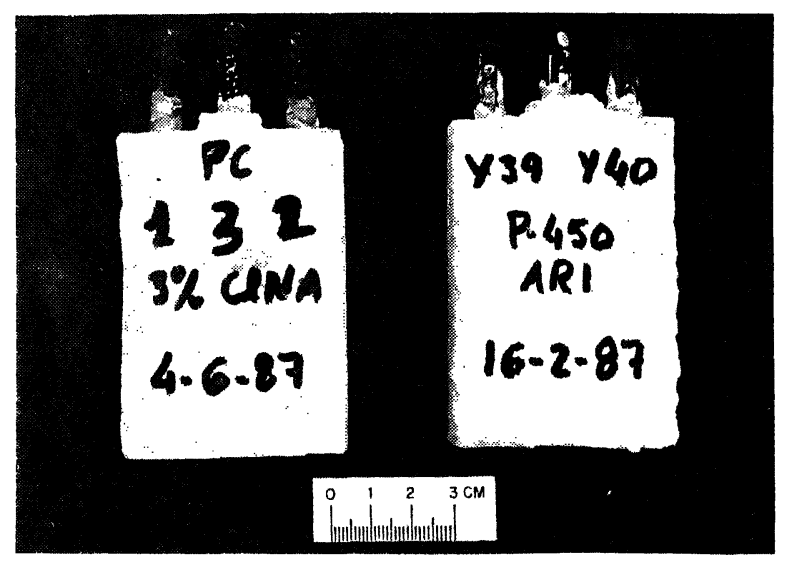

Fig. 2 
Para los ensayos tipo 2 de immersión en ciclos alternados en solución de cloruro sódico, se amasaron probetas idénticas a las del tipo 1 con cemento P-450-ARI que actuaron como testigos, y el resto se fabricaron de iguales dimensiones pero con el mortero de reparación $B$ siguiendo las instrucciones de amasado del fabricante. Los redondos que se embebieron en este caso, unos fueron sin pintar y otros pintados con la pintura $A$ (de la que hay que señalar que al secarse se cuarteaba).

Para los ensayos tipo 3 se fabricaron probetas idénticas al tipo 2 , pero una serie además contenía $3 \% \mathrm{NaCl}$ añadido en el agua de amasado y otra $3 \% \mathrm{CaCl}_{2}$.

Para el proceso de carbonatación acelerada, se introdujeron las probetas en una cámara saturada de $\mathrm{CO}_{2}$ y al $60 \%$ de HR. El avance de la carbonatación se controla mediante el aumento de peso debido a la incorporación de $\mathrm{CO}_{2}$. También se controla con la medida de

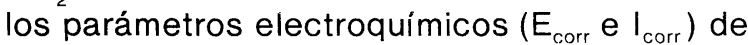
los sensores, como se describirá posteriormente. Finalizada la carbonatación, las probetas se someten a diversas humedades relativas para comprobar la permeabilidad de la pintura $\mathrm{C}$ al paso del vapor de agua.

Los ensayos de ciclos de inmersión en $\mathrm{NaCl}$ consistían en introducir las probetas $12 \mathrm{~h}$ en la solución y dejarlas secar durante otras $12 \mathrm{~h}$. Todos los días se hacian medidas de los parámetros electroquímicos, $E_{\text {corr }}$ e $\mathrm{I}_{\text {corr }}$, hasta detectar la despasivación de los sensores metálicos.

En cuanto a las probetas que contenían cloruros añadidos en el amasado, se conservaron todo el tiempo en cámara húmeda y se midió en ellos el $E_{\text {corr }}$ y la $I_{\text {corr }}$.

El potencial de corrosión, $\mathrm{E}_{\mathrm{corr}}$, se midió siempre con respecto al electrodo de calomelanos saturado, con un minivoltímetro. La intensidad de corrosión, $I_{\text {corr }}$, se midió con el método de Resistencia de Polirización (6).

\section{Resultados de los ensayos de carbonatación}

En la figura 3 se muestran los aumentos de pesos, en relación al peso inicial de la probeta, experimentados por las probetas con pintura $A$ y testigo durante el tiempo que permanecieron en la cámara de carbonatación.

Se puede observar como no se aprecia prácticamente diferencia en la velocidad de penetración del $\mathrm{CO}_{2}$ entre la probeta testigo y
For alternated cycles of immersion in solution of $\mathrm{NaCl}$, (tests of type 2), some specimens were moded identically to those of type 1 with ordinary portland cement and were used as blanks. Others were made with equal size but with the repairing mortar $B$ and following the mixing specifications given by the manufacturer. Rebars were embedded in this case as follows: Some were left without any paint and the other were painted with paint $A$ which showed marks of cracking as it was drying.

For tests of type 3, specimens were identical to the ones made for type 2, though a number had $3 \% \mathrm{NaCl}$ added to the maxing water and the other $3 \% \mathrm{CaCl}_{2}$.

For the accelerated carbonation process, the specimens were put into a saturated chamber of $\mathrm{CO}_{2}$ at $60 \% \mathrm{RH}$. The carbonation evolution was controlled by the increase of weight of the specimens due to the incorporation of $\mathrm{CO}_{2}$. The carbonation process is also controlled by the measurement of the electrochemical parametres ( $E_{\text {corr }}$ and $l_{\text {corr }}$ ) of the sensors, as it will be discussed below. When the carbonation process ends specimens are put to different relative humidities in order to verify the permeability of paint $C$ to water vapor.

Tests of immersion cycles in $\mathrm{NaCl}$ consisted in introducing the specimens in the $\mathrm{NaCl}$ solution during 12 hours and then, drying them during 12 additional hours. Electrochemica!

parametres $E_{\text {corr }}$ and $I_{\text {corr }}$ were measured every day till the despassivating of the metallic sensors was detected.

In relation to those specimens with chloride added to the mixing water, they were kept all the time in humid chambers in which $E_{\text {corr }}$ and $I_{\text {corr }}$ were measured.

The corrosion potential, $E_{\text {corr }}$, was always measured in relation to the calomel saturated by means of a potentiostat. The corrosion intensity, $I_{\text {corr }}$, was measured by the Polarization Resistance method, (6).

\section{Carbonation test results}

Fig. 3 shows the increase of weight of the specimens as function of the specimen initial weight along the time stayed into the carbonation chamber.

It can be observed that there is no difference in the penetration rate of $\mathrm{CO}_{2}$ between the blank specimen and the painted one. However, 
las pintadas ni aún en los primeros minutos. Sin embargo, sí se detecta una velocidad de absorción ligeramente inferior, de humedad en el mortero pintado, aunque en contrapartida el proceso de secado también parece algo más lento.

En la figura 4 se muestran los $E_{\text {corr }}$ (a) y los $I_{\text {corr }}$ (b) medidos simultáneamente durante el proceso de curado, carbonatación y conservación (al 100 \%, 80 \% y 50 \% HR).

Durante el proceso de curado las armaduras de ambas probetas alcanzan valores de $E_{\text {corr }}$ bastante positivas - $100 \mathrm{mV}$ que se corresponden con valores bajos de velocidad de corrosión por debajo de $0,2 \mu \mathrm{A} / \mathrm{cm}_{2}$, lo que indica que las armaduras están pasivas en estas circunstancias.

Cuando se inicia la carbonatación de las probetas se observa, simultáneamente para ambas probetas pintadas y sin pintar, fuertes descensos del $E_{\text {corr }}$ e incrementos de la $I_{\text {corr }}$, lo it is detected a slightly lower absorption rate of humidity in the painted mortar, though it is somehow compensated by the fact that the drying process seems to be little slowlier indeed.

Fig. 4 shows $E_{\text {corr }}$ (a) and $I_{\text {corr }}$ (b) simultaneously measured during the curing, carbonation and conservation (at $100 \%, 80 \%$ and $50 \% R H$ ).

During the curing process, the reinforcements of both specimens reach $E_{\text {corr }}$ values rather positive, - $100 \mathrm{mV}$, which corresponds to low corrosion rate values, below $0.2 \mu \mathrm{A} \mathrm{cm}^{2}$, whats points out that the reinforcements are passive in these conditions.

When the carbonation process on the specimens begins, it is simultaneously observed, for both painted and not-painted specimens, sudden decreases of the $E_{\text {corr }}$ and

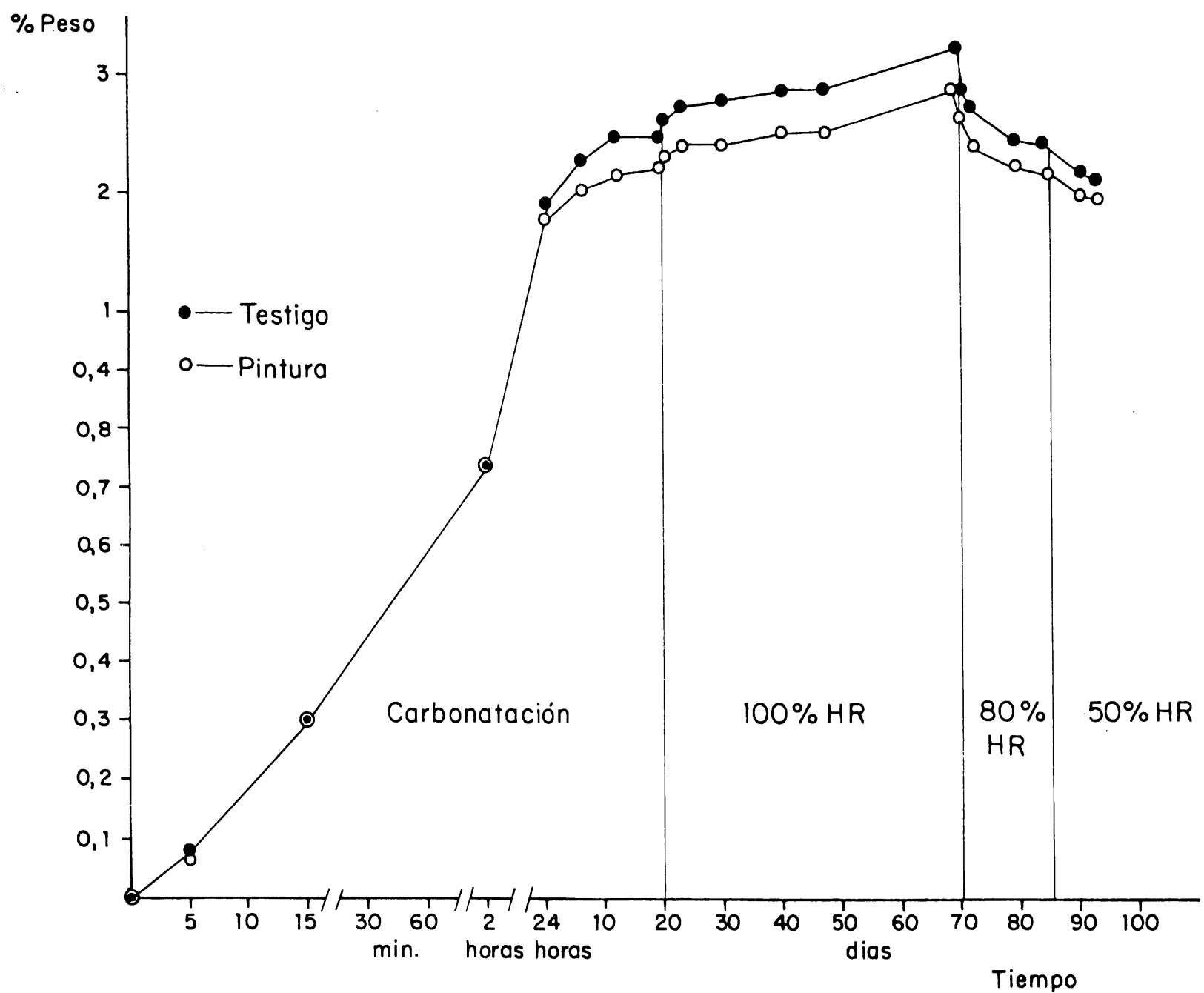

Fig. 3 

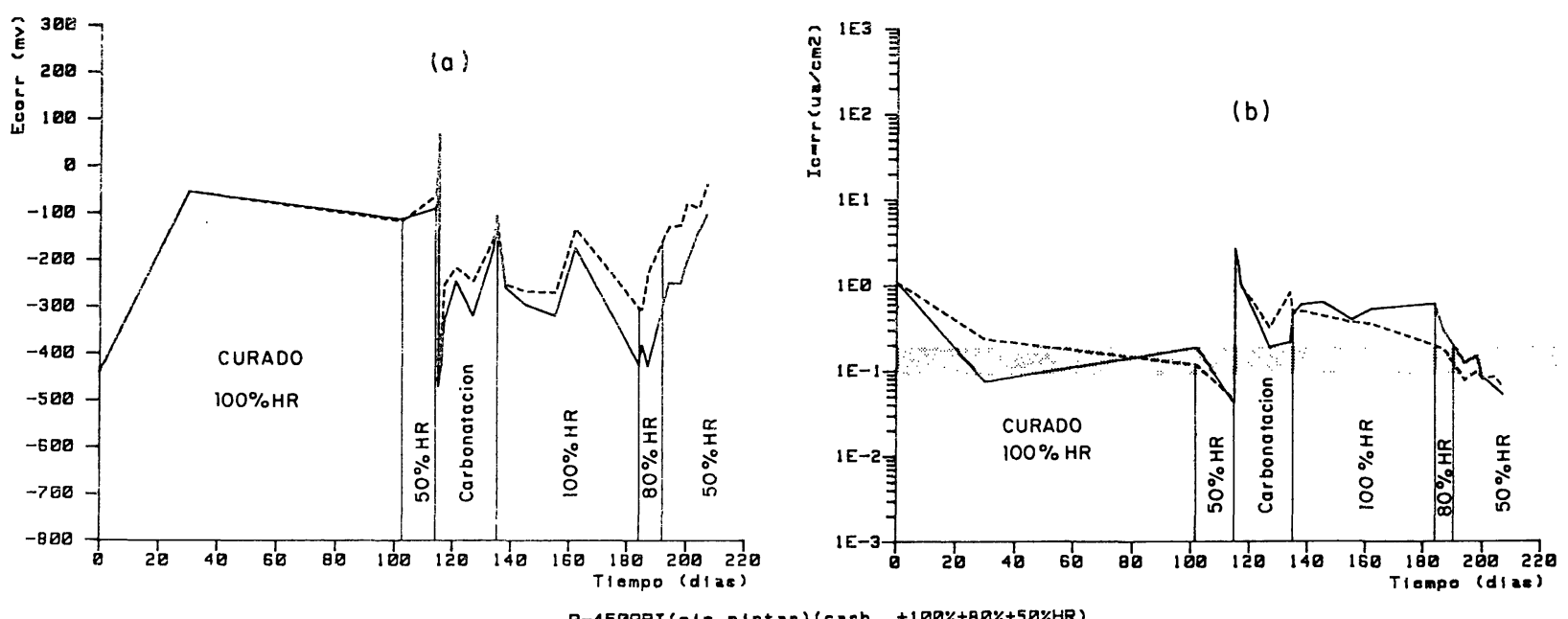

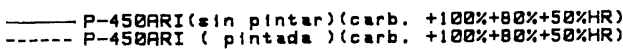

Fig. 4

que indica que el frente carbonatado llega rápidamente hasta las proximidades de las armaduras provocando la ruptura de la capa pasiva en éstas. Los descensos de $\mathrm{I}_{\text {corr }} \mathrm{O}$ incrementos de $E_{\text {corr }}$ que se observan en las medidas tomadas durante la carbonatación se explican porque al agotarse toda la materia carbonatable, el $\mathrm{H}_{2} \mathrm{O}$ formada en el proceso comienza a evaporarse. Al reducirse la humedad disminuye entonces la velocidad de corrosión, pero este descenso es más lento en las armaduras de las probetas pintadas, ya que se secan más despacio, que en las de sin pintar.

Cuando las probetas una vez carbonatadas se conservan al $100 \% \mathrm{HR}$, se produce un incremento de la velocidad de corrosión junto un descenso del $E_{\text {corr }}$. Estas variaciones son más lentas en las probetas pintadas, hecho que se puede explicar porque la pintura ofrece una resistencia a la penetración de la humedad.

Al pasar a humedades inferiores $(80 \%$ y $50 \%$ $H R$ ), las velocidades de corrosión descienden y los potenciales tienden simultáneamente a valores más positivos, lo que indica que la armadura aunque el entorno esté carbonatado, a humedades bajas deja de peligrar porque el proceso de corrosión está impedido por la elevada resistividad del medio.

Sin embargo estos descensos de velocidad de corrosión a bajas humedades aunque parecen más rápidas en las probetas pintadas, en realidad no lo son, ya que la cantidad de humedad absorbida también fue in'erior lo que da lugar a velocidades de corrosión más bajas, pero al cabo de un cierto tiempo de permanecer al $50 \% \mathrm{HR}$. Las velocidades de corrosión de las probetas sin pintar se hacen increases of the $I_{\text {corr }}$, what means that the carbonation front reaches quickly the reinforcements producing a break of their passive film. Later, decreases of $I_{\text {corr }}$ and increses of $E_{\text {corr }}$ obtained during the carbonation are explained by the fact that as carbonatable product is exhausted, the water formed in the process starts to evaporate. As humidity value decreases corrosion rate also decreases, though this drop is slowlier in painted specimens because they dry faster than not painted ones.

When carbonated specimens are kept at $100 \%$ $\mathrm{RH}$, it is produced an increase of the corrosion rate along with a decrease of the $E_{\text {corr }}$. These variations are slowlier in painted specimens, what can be explained by the fact that paint resists humid penetration.

At lower humidities ( $80 \%$ and $50 \% R H)$, corrosion rates decrease and corrosión potentials tend simultaneously to reach more positive values what means that the reinforcement at low humidities, though its surroundings may be carbonated, is safe because the corrosion process is not allowed due to the high resistivity of the system.

Although the decrease of the decrease of the corrosion rate at low humidity values seems to be faster in painted specimens, it is not true because the amount of humidity is also lower and this gives as result lower corrosion rates. After staying some time at $50 \% \mathrm{RH}$, the corrosion rate in not painted specimens are lower than in painted ones, what points out that not painted specimens lose water 
inferiores a las de las pintadas, lo que indicaría que las probetas sin pintar pierden el agua más rápidamente que la pintada. Todo ello está en concordancia con lo que se observó durante el proceso de carbonatación.

Del análisis de estos resultados se puede deducir que la pintura de recubrimiento exterior de mortero no mejora la resistencia a la carbonatación del mismo. Sí mejora, sin embargo, la resistencia a la penetración de humedad, pero por otra parte una vez dentro, esta humedad se elimina más lentamente.

\section{Capacidad protectora del mortero de reparación}

En la figura 5 se representan los potenciales de corrosión (a), $E_{\text {corr }}$, e intensidad de corrosión (b) $I_{\text {corr }}$ medidos en armaduras sin pintar embebidas en probetas de mortero fabricado con cemento P-450-ARI y en armaduras pintadas embebidas en el mortero de reparación. Se observa como en ambos casos se alcanzan a los 8 días valores de potencial bastante anódicos, entre - 200 y - $100 \mathrm{mV}$ aunque éstos inicialmente son mucho más negativos en las armaduras del mortero de reparación. Las intensidades de corrosión medidas, son muy similares en ambos casos y también a los 8 días se alcanza el límite de $0,2 \mu \mathrm{A} / \mathrm{cm}^{2}$ (zona rayada) que se considera como de pasivación, lo que indica que la velocidad a la que se disuelve el material base es muy baja. De estos ensayos se deduce que el mortero de reparación tiene capacidad pasivante y protectora hacia las armaduras.

\section{Comportamiento del mortero frente a los cloruros que penetran desde el exterior}

Para las mismas probetas ensayadas en la figura 5, tras conocer su comportamiento hasta los 40 días después del amasado y comprobar que la pasivación de las armaduras se ha alcanzado, se ensayó lo que ocurría frente a la penetración de cloruros desde el exterior. Para ello como ya se mencionó, se introdujeron las probetas en salmuera con ciclos diarios de mojado (por la noche) y secado durante el día. En el caso de las probetas fabricadas con el mortero de reparación se procedió a un sellado de todas las fisuras visibles con cera vegetal.

Los resultados de $E_{\text {corr }}$ e $I_{\text {corr }}$ se dan en la figura 6 , partes a y $b$.

Se comprueba que la llegada de los cloruros hasta la armadura en cantidad suficiente se produce muy rápidamente, ya que se detecta quicklier than painted ones. All these facts agree with the results obtained during the carbonation.

From these results, it can be deduced that the external paint covering of the mortar does not improve its resistance to carbonation. On the other hand, its resistance to humid penetration is improved, though, for the same reasons, humidity is slowly removed when it has just penetrated into the structure.

\section{Protecting capacity of the repairing mortar}

Fig. 5 shows the corrosion potentials, $E_{\text {corr }}(\mathrm{a})$ and corrosion intensity, $I_{\text {corr }}(b)$, measured in not painted bars embedded in mortar specimens made with ordinary portland cement and painted bars embedded in repairing mortar $B$. It is observed that for both cases, potential are rather anodical, about -200 and -100 $m V$, reached in 8 days, though these values are initially more negatives in the bars of the repairing mortar. The corrosion intensities measured for both cases are similar and they reach the value of $0.2 \mu \mathrm{A} / \mathrm{cm}^{2}$

(shadowed zone), considering this value as the passivating one, in the first 8 days, what points out that the rate in dissolving the base material is very low. According to the tests, it can be deduced that the repairing mortar has passivating and protecting capacity towards the reinforcements.

\section{Mortar behaviour to the penetration of chlorides}

For the same specimens tested in Fig. 5, their behaviour when put to an external penetration of chlorides was tested. This part of the test started 40 days after the mixing when the passivation of the rebars was reached, in order to test the specimen behaviour response to chloride, they were daily put into a saturated solution of $\mathrm{NaCl}$, according to the cycle: wet at night and dry along the day. In the case of specimens made with the repairing mortar, external, fissures were sealed with vegetal wax.

It is verified that the penetration of enough amount of choloride near the reinforcements produces quickly, as a break of their passivating film is detected by a sudden increase of the corrosion rate. This increase of the corrosion rate seems to be slowlier at early stages in 
una ruptura de la capa pasiva que se manifiesta con un fuerte incremento de la velocidad de corrosión. Este incremento de la velocidad de corrosión parece más lento al principio en las armaduras del mortero de reparación cubiertas con pintura $A$. Este efecto se ha atribuído precisamente a la capa de pintura que deben atravesar los cloruros antes de entrar en contacto directo con la armadura. Pero sin embargo, una vez que esto ocurre la velocidad de corrosión se incrementa y se hace considerablemente más elevada que en las armaduras sin pintar y mortero de P-450-ARI. El resultado final es un mayor ataque en las armaduras recubiertas de pintura, donde óxidos de color marrón, negro y verde oscuro se almacenan en mayores cantidades bajo la pintura. También aparecen estos óxidos en las armaduras embebidas en mortero de cemento P-450-ARI, pero de forma más local (en parte derecha están las armaduras embebidas en el mortero de reparación, manchas más oscuras) (fig. 7).
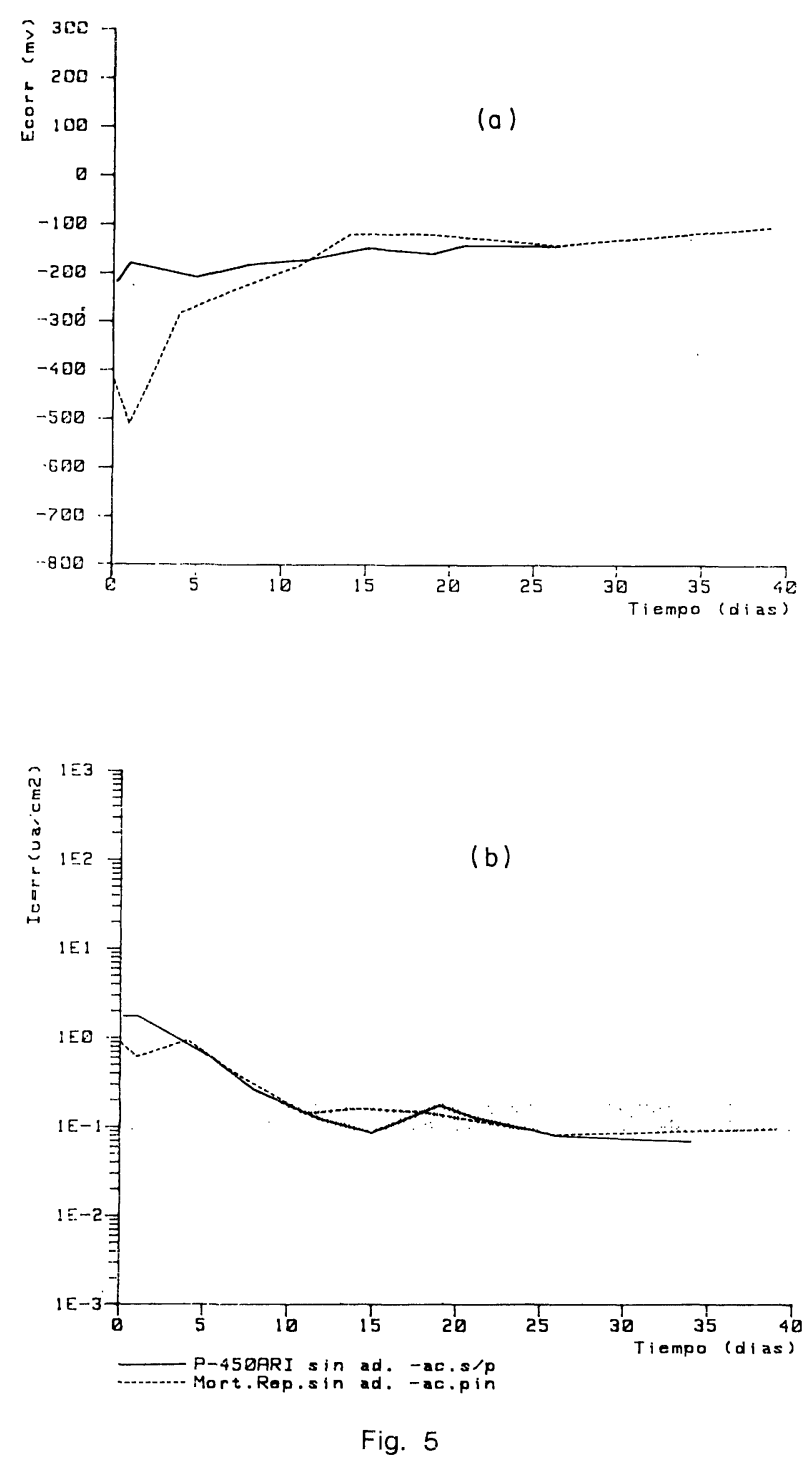

those reinforcements of the repairing mortar with paint $A$. This effect has been attributed to the paint film because chloride must go through it before coming into contact with the rebars. Nevertheless, the corrosion rate increases as chlorides come into contact with rebars and it is remarkably higher than in not painted rebars and mortars made with oridinary portland cement. It is concluded that there is a higher attack intensity in painted rebars, where large amounts of brown, black and dark green oxides are storaged under the paint. These oxides are also found in rebars embedded in mortar made of ordinary portland cement, though only locally, as shows Fig. 7, on the right, are the bar embedded in the repairing mortar, darker spots.
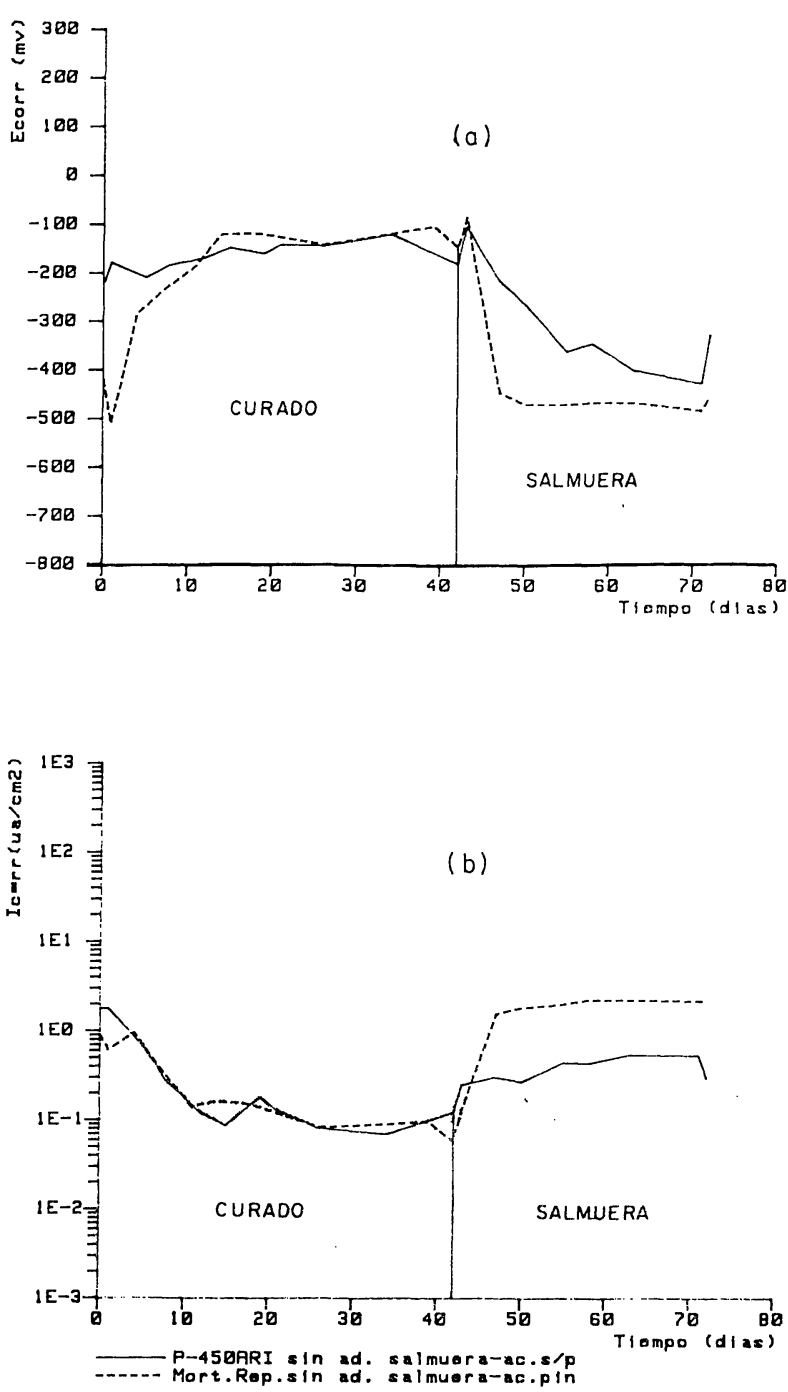

Fig. 6 


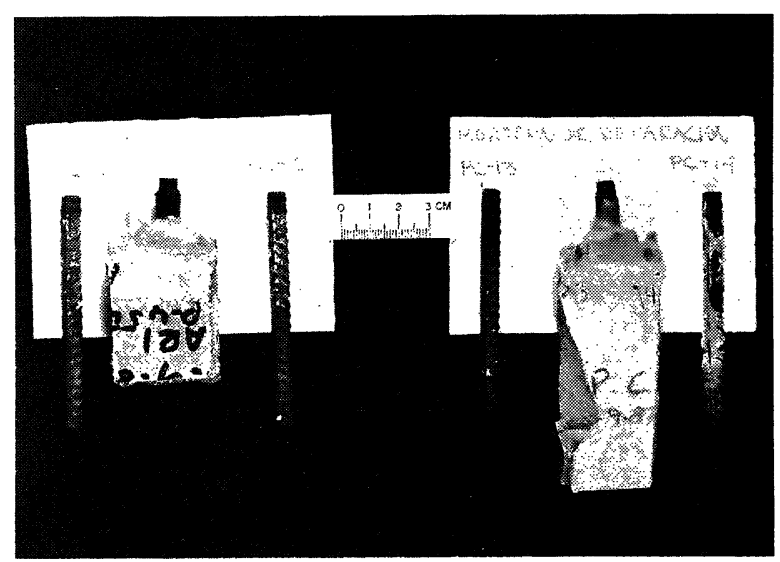

Fig. 7

Comportamiento del mortero de reparación frente a los cloruros añadidos en el momento del amasado

En la figura 8 se dan los resultados de $E_{\text {corr }}(a)$ e $\mathrm{I}_{\text {corr }}$ (b) de armaduras pintadas con $\mathrm{A}$ y sin
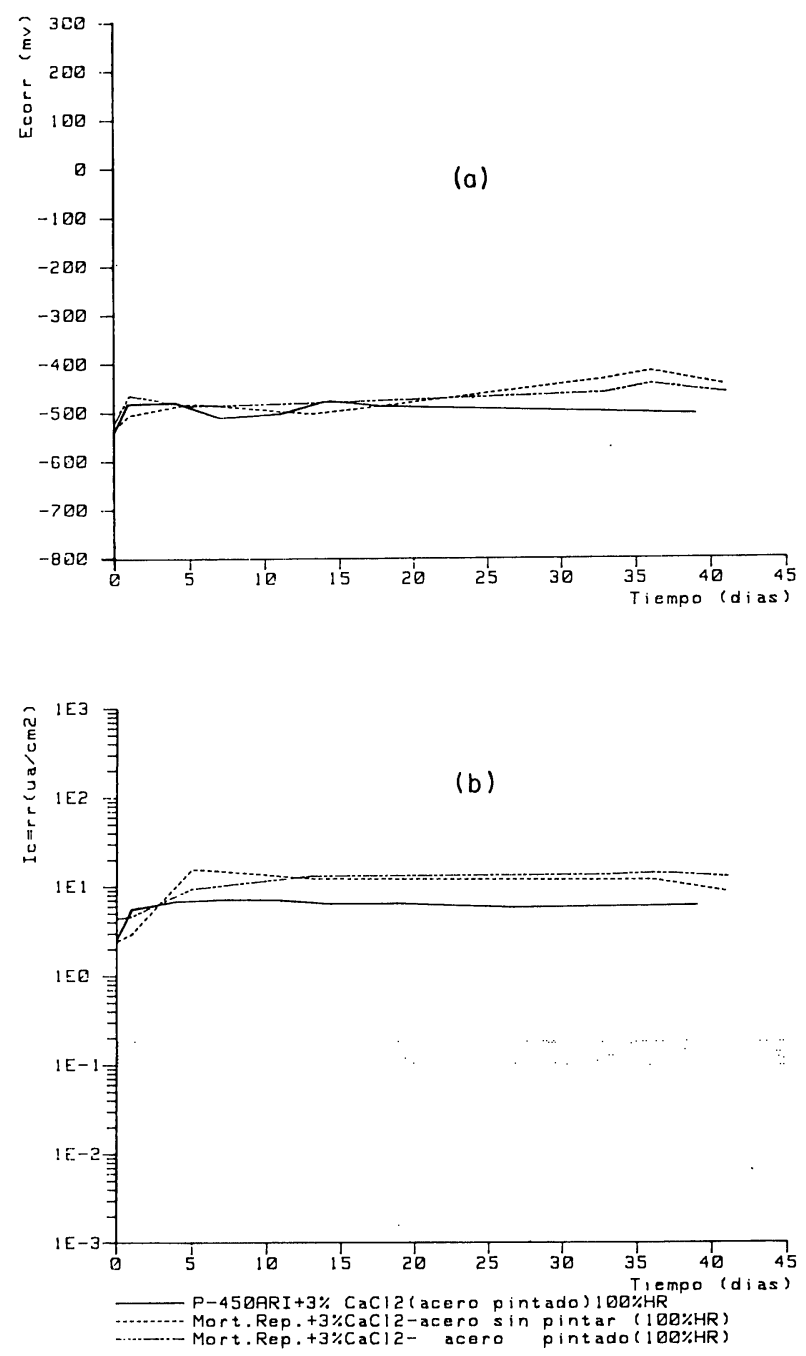

Fig. 8

\section{Repairing mortar behaviour to chlorides} added in the mixing

Fig. 8 shows the results of $E_{\text {corr }}(a)$ and $I_{\text {corr }}(b)$ obtained in painted $(A)$ and not painted rebars.
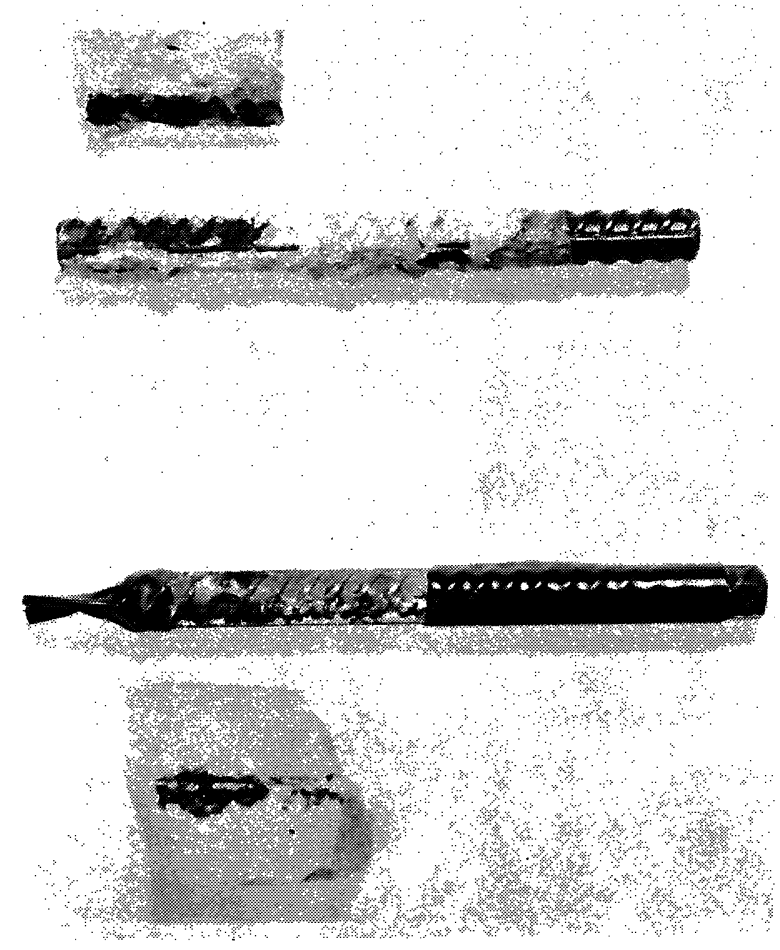

Fig. 9 
pintar. En cuanto a los potenciales ( 8 a) son bastante bajos (de -450 a $-550 \mathrm{mV}$ ) en todos los casos, lo que indica elevada actividad sobre los aceros. Este hecho se confirma de nuevo al medir las velocidades de corrosión (8 b) que se aprecian bastante elevadas, y aún superiores en el caso de ias del mortero de reparación. El mejor comportamiento de las armaduras en mortero de P-450-ARI con $3 \%$ de $\mathrm{NaCl}$ puede atribuirse a varios factores (cuya confirmación exigiría ensayos más detallados): uno podría ser un mayor contenido en Aluminato tricálcico del cemento ARI que se combinaría con los $\mathrm{Cl}^{-}$formando cloroaluminatos y disminuyendo la concentración de cloruros libres agresivos en el medio y otro podría ser una mayor reserva alcalina del cemento ARI. La conclusión es que el ataque hacia las armaduras embebidas en el mortero de reparación es más elevada tanto en el acero pintado como sin pintar como así se aprecia en la figura 9.

Es importante destacar que aunque la pintura que recubre el acero no mejora el
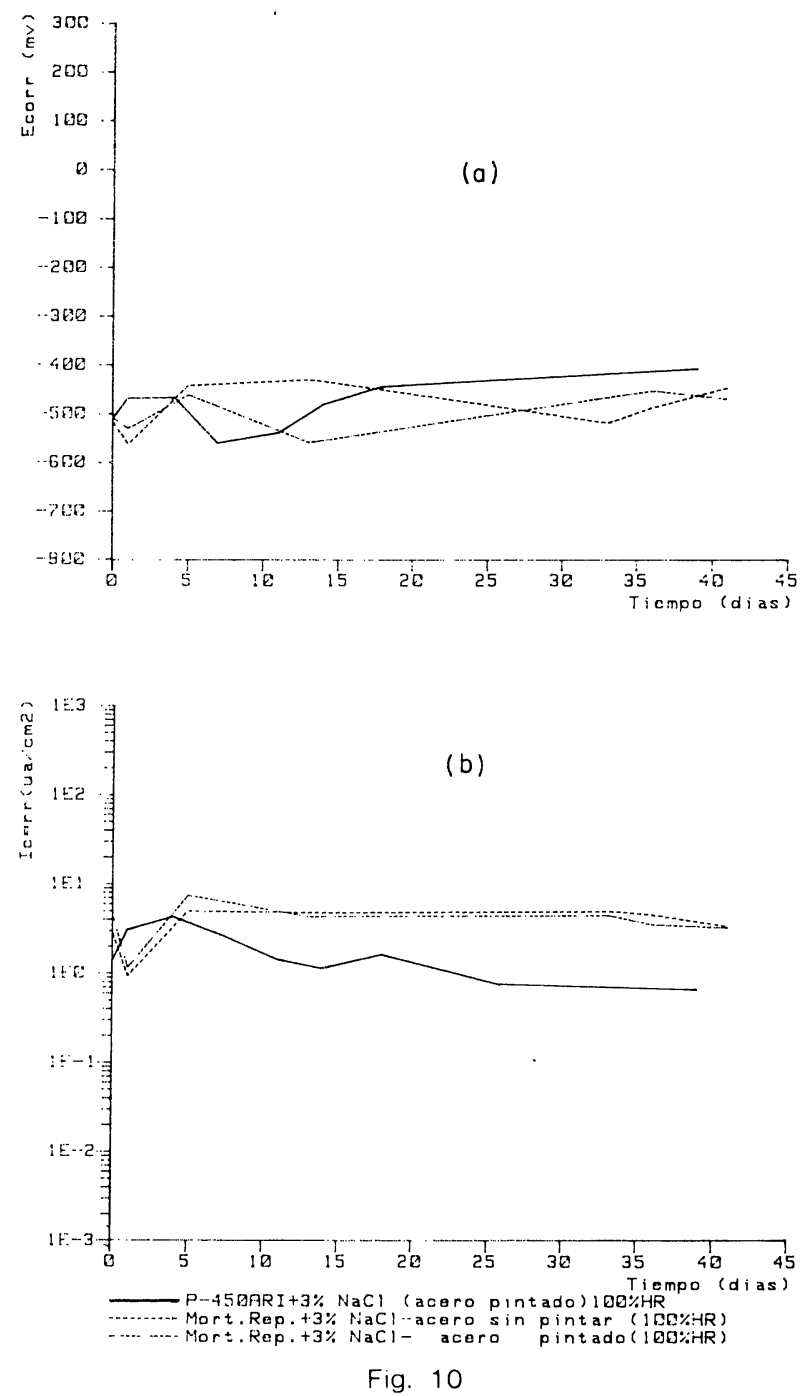

Corrosion potentials (8a) are rather low $(-450$ to $-550 \mathrm{mV}$ ) for all cases, what points out high activities on the steels. This fact is verified again by the high corrosion rates measured (8b), which are even higher for the repairing mortar. The better behaviour of the reinforcement in ordinary portland cement mortars and $3 \% \mathrm{NaCl}$ can be attributed to different facts (although, some more tests would be needed in order to verify these conclusions): one of these facts could be found in the larger amounts of $\mathrm{CaCl}_{2}$ in ordinary portland cement which would combine with $\mathrm{Cl}^{-}$and give as result chloride aluminate which reduces the concentration of free and aggresive $\mathrm{Cl}^{-}$in the medium. Other fact could be the larger amount of alkaline reserve in ordinary portland cement. Thus, it is concludes that the attack to rebars ambedded in the repairing mortar is as higher in painted and not painted steels as shows Fig. 9.

It should be remarked that a painted film on the steels does not improve their behaviour to

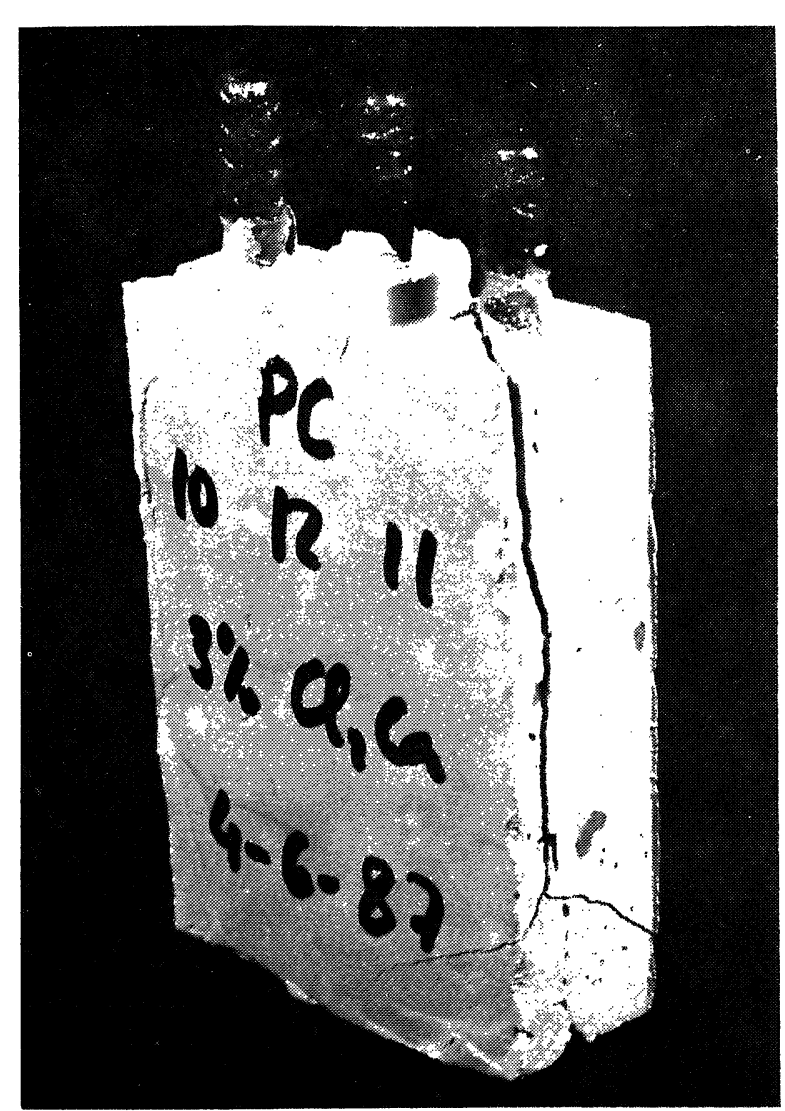

Fig. 11 
comportamiento frente a la corrosión de armaduras, sin embargo si mejora la adherencia acero-mortero de reparación, ya que al romper la probeta fue difícil separar el mortero de la pintura y ésta lo hace antes del acero, especialmente si hay óxido debajo.

En cuanto a las probetas amasadas con $3 \%$ $\mathrm{CaCl}_{2}$ se midieron también potenciales de corrosión en todos los casos muy negativos, alrededor de $-500 \mathrm{mV}$ (figura 10 a) y las velocidades de corrosión (parte $b$ en la figura 10) son también muy elevadas (superiores como es habitual al caso de usar $\mathrm{NaCl}$ ) aunque también aquí son algo inferiores para las armaduras en mortero amasado con P-450-ARI.

Debido a la gran cantidad de óxidos formados en estas condiciones, las grietas que por retracción ya de por sí aparecen en el caso del mortero de reparación se hacen aún más patentes como se aprecia en la figura 11.

\section{Conclusiones sobre el sistema de reparación empleado}

El sistema de los materiales compuestos por una pintura de armaduras, un mortero sin retracción y una pintura anticarbonatación, no se considera idóneo, ya que:

- La pintura de recubrimiento de mortero $\mathrm{C}$ empleada no mejora la resistencia frente a la carbonatación y sólo ligeramente frente a la penetración de humedad.

- El mortero de reparación B aunque protector en ausencia de agresivos frente a las armaduras, se fisura durante el curado y resulta más permeable que un mortero tradicional $1 / 3$ a la penetración de cloruros desde el exterior.

- La pintura aplicada sobre las armaduras A no mejora el comportamiento frente a la corrosión en presencia de agentes agresivos pero favorece la adherencia entre el sistema: acero pintura-mortero.

Todo ello hace prever que si no se hubieran tomado precauciones especiales para conducir las aguas de deshielo y lluvias lejos de los paramentos de hormigón, los cloruros volverian rápidamente a penetrar y la corrosión comenzaria de nuevo. Asímismo se ha recomendado al concesionario del viaducto que proceda a un nuevo pintado de las alas exteriores, con una pintura lo más impermeable posible al paso de los cloruros, ya que todas las que cumplen este requisito son además "anticarbonatación", lo que no ocurre con la viceversa, como se ha comprobado en los ensayos. corrosion, though the steel repairing mortar system adherence is improved as it is rather difficult in breaking the specimen, to separate the mortar from the paint, and this is easier from the steels, especially when there are oxides under the paint film.

In relatio to the specimens mixed with $\mathrm{CaCl}_{2}$, it was also measured the corrosion potentials which were very negative for all cases, arround - $500 \mathrm{mV}$ (Fig. 10a). Corrosion rates (Fig. 10b) were also very high (higher than those case with $\mathrm{NaCl}$ additions), though in this case, they are also slightly lower for reinforcements in mortars with ordinary portland cement. Due to the large amounts of oxide formed in these conditions, the retraction fissures that appear in repairing mortar $B$ are even more evident as shows Fig. 11.

\section{Conclusions on the repairing system employed}

The repairing system made up of paint for rebars, mortar without retraction and anticarbonation paint are not suitable accordiong to the following conclusions:

- The covering mortar paint $C$ used does not improve resistance to carbonation and only slightly improves resistance to humidity penetration.

- Repairing mortar (B), though protective when there are no aggressive agents, is cracked during the curing process and it is more permeable to external chloride penetration than the traditional 1/3 mortar

- Paint (A) applied to reinforcements does not improve behaviour to corrosion of aggressive agents though steel-paint mortar system adherence is favoured.

For all these reasons, it is concluded that if no additional caution to eliminate malted-ice and water rain from the concrete surface is taken, chloride would penetrate quickly into the structure and corrosion would restart. In addition, it is also recommended to the viaducts resposible to paint the external wings with a most chlorideimpermeable paint, as all paints which satisfy this requirement are also "anticarbonation", but not the other way round, as the tests have proved. 


\section{CONSIDERACIONES FINALES}

Los ensayos realizados revelan cómo productos, en principio de calidad y que cumplen las condiciones de: adherencia al soporte, rápido fraguado, buena resistencia mecánica a corto plazo, etc. ... pueden no resultar más adecuados para la función que deben cumplir que un mortero normal bien dosificado, con todos los graves perjuicios económicos que ésto acarrea. De ello se deduce la urgente necesidad de contar con recomendaciones de ensayo o normativas adecuadas al uso al que se les va a someter.

Los requisitos esenciales que se deben exigir a estos productos, cuando se utilicen para reparar obras dañadas por corrosión de armaduras (además de las especificaciones básicas ya contempladas) pueden resumirse en:

- Mortero de reparación: a) en el caso de materiales de base cemento, alcalinidad elevada que favorezca la repasivación del acero, baja permeabilidad y ausencia de fisura (retracción) y b) en el caso de materiales de base orgánica, es necesario garantizar una buena adherencia al acero, perfecta estanquidad y muy lento envejecimiento $\sin$ retracciones.

- Pinturas y revestimientos: deben tener capacidad impermeabilizante frente a los cloruros, el anhídrido carbónico y la humedad ambiental, según sea necesario.

\section{FINAL CONSIDERATIONS}

These tests point out how materials of good quality which satisfy the requirements of supporter adherence, fast setting, good mechanical resistances at early ages, ... ect may not fit the functional conditions that a well-dosaged mortar should satisfy, with all the serious economical problems it may produce. For this reason, it is urged to take into account suitable test specifications of use which they are going to develop.

The essential requirements that should be demanded to these materials when they are going to be employed in repairing structures damaged by corrosion of reinforcements can be summarised as follows (basical specifications just mentioned should also be taken into account):

- Repairing mortar: a) for materials of cement based: it should be required a high alkalinity degree which favour steel repassivating, low permeability and no retraction Fissures and b) for orgnic made materials, it is necessary to guarantee a good adherence to the steel, perfect isolation and a very slow oldness without retraction.

- Paints and films: they should have impermeabilizing capacity to chloride, $\mathrm{CO}_{2}$ and enviromental humidity, according to the specific conditions of the medium.

\section{BIBLIOGRAFIA}

REFERENCES

(1) $\mathrm{ACl}$ 503-R-80: use of epoxi compounds with concrete.

(2) FERNANDEZ CANOVAS, M. (1974): Las resinas epoxi en la construcción. Ed. IETcc.

(3) GUIDE GENERAL (1985): Les techniques de réparation et de reforcement des ouvrages en béton. Fascicule 1 STRRES-FNTP-AFPC-SNBATI.

(4) ASTM-876 (1986): Half cell potentials in reinforcing steel in concrete.

(5) FELIU S., GONZALEZ, J. A., ANDRADE C., FELIU, V. (1987): On site deconcrete beam. NACE CORROSION-87. S. Francisco March Paper núm. 145.

(6) ANDRADE C., GONZALEZ J. A. (1978): Quantitative measurements of corrosion rate of reinorcing steels embedded in concrete using polarization resistance measurements. Werkstoff unf Korrosion, 29, 515-519. 